An Introduction to Medical Genetics By Dr. J. A. Fraser Roberts. Second edition. Pp. $x+263$. (London and New York: Oxford University Press, 1959.) 35s. net.

7 HE author looks forward to the day when genetic knowledge is so perfectly incorporated into medicine that specialists in medical genetics are no longer needed. The complexities of human biology would seem to make this a distant and perhaps unrealizable future, and it must also be admitted that little positive work has been done in the past to show the clinician or medical student how genetic principles may be put to use in ordinary clinical practice. Recent discoveries relating blood group frequencies to specific diseases have generated a new interest and the present book, a second edition appearing nineteen years after the first, is an admirable introduction to the subject, illustrated exclusively by medical examples and almost wholly deductive and non-mathematical in treatment. It is designed for the clinician or senior student with a real interest in learning something about medical genetics. The point of view is clinical and based on the affected individual : eugenics and the public health are not discussed. The average medical student may well find the book too demanding, but he should nevertheless be made to read the last chapter, on genetic prognosis. Here is a lucid description of how anxious parents can be accurately helped in one of the most critical decisions they will ever have to make, whether to have more, or even any, children. Precise and sometimes extensive knowledge is an essential prerequisite and in this field also the practitioner should know when to call in the specialist.

Very recent advances in human cytogenetics, which it was possible to refer to in a postscript, have already led to spectacular discoveries, and new observations are being reported almost monthly. After sufficient time for their proper digestion a third edition will surely be called for. The opportunity might then be taken to consider how the actions of doctors affect the genetics of the human race and of particular individuals, not only through the mutagenic effect of the medical uses of radiation, and perhaps of drugs, too, but also through the effects of medical treatment in preserving individuals carrying deleterious genes so that they reach the age of marriage and reproduction.

R. H. Mole

\section{The Reach of Science}

By Prof. Henryk Mehlberg. Pp. xii + 356. (Toronto : University of Toronto Press ; London: Oxford University Press, 1958.) 45s. net.

THIS book is an able study in the philosophy of science. If it seems, in part, a little heavy. handed, the reader must accept that as something to be paid for the author's careful approach, and his concern to avoid misunderstandings. There are three main parts : the concept of scientific knowledge, the method of science, and the universality of science. It is a little difficult to state exactly where the writer stands, but he is evidently a liberal upholder of the "logical inherent universality of seience" rather than of the rigid positivism stemming from Comte, who, in the event, has not proved a very constructive influence in research.

Prof. Mehlberg makes a good point in bringing under one critical comment both historicism and psychologism. The errors are parallel; in the first case to see in history the sole explanation of some- thing, in the second to assign to subjectivism an excessive share in the unravelling of causes.

The urge to believe that "whatever is knowable is scientifically knowable" is excellent so far as it goes. It is hard to credit nevertheless that the author intends to press his thesis to the limit, in view of countless lives lived both rewardingly and beneficently without so much as a shred of 'knowledge' as thus defined.

F. I. G. Rawhins

The World of Learning, 1959-60

Tenth edition. Pp. xiii +1221. (London: Europa Publications, Ltd., 1960.) 140s. net.

" TCHE World of Learning" continues in its now established form and hence remains a most valuable comprehensive compilation of academic organizations throughout the world. It includes details of Unesco, giving its origin, aims, functions and activities, and followed by alphabetical treatment of the academic institutes of each of the member countries. It includes learned societies, research institutes, libraries and archives, museums and art galleries, universities, colleges and technical institutes. The entry for each institute contains its address, the names of the leading officials, and in most cases a list of professors is provided. The compilation ends with a thorough sixty-four page index of all the institutes covered. It is regretted, however, that the editors have still not been able to gain the full co-operation of U.S.S.R. institutes, and the total contribution by the U.S.S.R. remains at twenty-eight pages. The work loses some of its usefulness by still not having a name index.

\section{Chemical Process Principles}

By Prof. Olaf A. Hougen, Prof. Kenneth M. Watson and Prof. Roland A. Ragatz. Part 2: Thermodynamics. Second edition. Pp. xviii $+505-1072+$ xix-lvi. (New York: John Wiley and Sons, Inc.; London: Chapman and Hall, Ltd., 1959.) 78s. net.

$T$

HIS is a completely revised edition of a book first published in 1947. After an introductorybut not elementary - chapter on thermodynamic principles, the authors present an extensive chapter on the properties of pure fluids, mainly based on the Lyderson-Greenkorn-Hougen three-parameter modification of the theorem of corresponding states. The rest of the book can be divided into three parts. In the first part the authors discuss the aspects of thermodynamics that are of particular interest to mechanical engineers, such as fluid-flow, power production, propulsion, and refrigeration. The second part is concerned with solutions, vapourliquid equilibria, and separation processes. The last three chapters deal with chemical equilibria in simple and complex reactions. This edition is enlarged as well as improved. Stress is laid on fundamentals, and it has been skilfully brought up to date. It is a comprehensive work at a level far more advanced than most currently available text-books, and will hold an important place in the university class-room as well as on the reference shelf. If it has a fault, it is that of obscurity, particularly in the first chapter. This is no primer, and the unversed reader will be well advised to choose another book. The informed reader, on the other hand, will find it a valuable addition to his collection.

L. E. Marc de Chazal 